\title{
Jaringan Syaraf Tiruan Backpropogation dalam Memprediksi Jumlah Tilang di Kejaksaan Negeri Simalungun
}

\author{
Sony Irwanda ${ }^{1}$, Jaya Tata Hardinata ${ }^{2}$, Irfan Sudahri Damanik ${ }^{3}$ \\ STIKOM Tunas Bangsa Pematangsiantar \\ sonyirwanda3@gmail.com, jayatatahardinata@gmail.com, irfansudahri@gmail.com
}

\begin{abstract}
This study predicts the number of ticketing by applying Artificial Neural Networks. The application uses the Backpropogation algorithm where the data entered is the number of tickets. Then an Artificial Neural Network is formed by determining the number of units per layer. After the network is formed training is carried out from the data that has been grouped. Experiments are carried out with a network architecture consisting of input units, hidden units, output units and network architecture. Testing is done with Matlab software.
\end{abstract}

Keywords :Prediction, Artificial Neural Networks, Tickets, Backpropogation, Matlab.

Abstrak- Penelitian ini memprediksi jumlah tilang dengan menerapkan Jaringan Syaraf Tiruan. Penerapannya menggunakan Algoritma Backpropogation dimana data yang diinputkan adalah jumlah tilang. Kemudian dibentuk Jaringan Syaraf Tiruan dengan menentukan jumlah unit setiap lapisan. Setelah jaringan terbentuk dilakukan training dari data yang telah dikelompokkan tersebut. Percobaan dilakukan dengan arsitektur jaringan yang terdiri dari unit masukan, unit tersembunyi, unit keluaran dan arsitektur jaringan. Pengujian dilakukan dengan perangkat lunak Matlab.

Kata Kunci : Prediksi, Jaringan Syaraf Tiruan, Tilang, Backpropogation, Matlab.

\section{PENDAHULUAN}

Kecerdasan buatan juga mengembangkan aplikasi - aplikasi yang dapat diaplikasikan dalam kehidupan nyata. Bisa digunakan dalam memprediksi hal - hal yang akan terjadi. Salah satu kecerdasan buatan yang dapat memprediksi sesuatu yang akan terjadi adalah Backpropogation. Salah satunya memprediksi jumlah tilang. Selain untuk membuat terciptanya kepatuhan dan budaya keamanan dan keselamatan berlalau lintas, tilang dilakukan untuk melindungi pengendara. Kejaksaan Negeri Simalungun merupakan kejaksaan yang menangani masalah tilang yang ada di Kabupaten Simalungun. Penanganan perkara tilang di Kejaksaan Negeri Simalungun sering mengalami kendala salah satunya menentukan jumlah kuota sidang kejaksaan terhadap pengadilan yang dapat mempermudah untuk menentukan jadwal sidang tilang yang sesuai dengan jadwal kejaksaan dan jadwal pengadilan. Untuk mengatasi masalah yang kompleks penulis menggunakan jaringan syaraf tiruan dengan menggunakan metode Backpropogation.

\section{METODELOGI PENELITIAN}

Kecerdasan Buatan (Artificial Intelligence atau AI) didefinisikan sebagai kecerdasan yang ditunjukkan oleh suatu entitas buatan. Sistem seperti ini umumnya dianggap komputer. Kecerdasan diciptakan dan dimasukkan ke dalam suatu mesin (komputer) agar dapat melakukan pekerjaan seperti yang dapat dilakukan manusia [1]-[3]. Beberapa macam bidang yang menggunakan 
kecerdasan buatan antara lain sistem pakar, permainan komputer (games), logika fuzzy, jaringan syaraf tiruan dan robotika [4].

Jaringan Saraf Tiruan (JST) merupakan salah satu representasi buatan dari otak manusia yang selalu mencoba untuk mensimulasikan proses pembelajaran otak manusia tersebut [5].

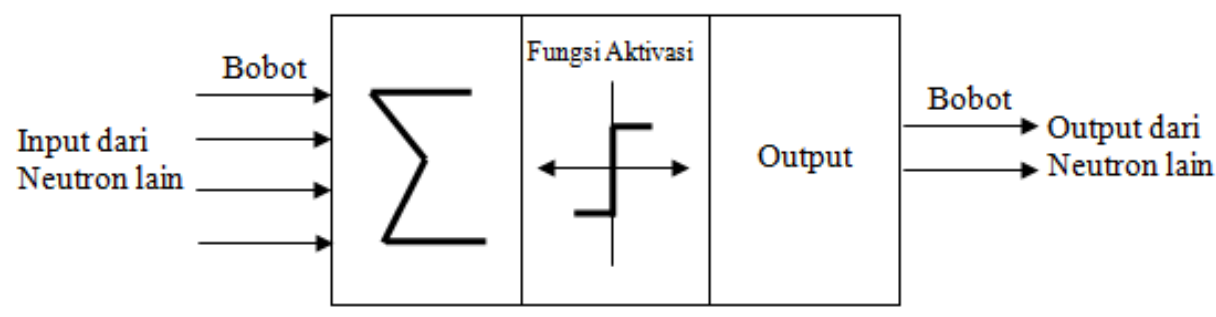

Gambar 1. Struktur Neuron Jaringan Syaraf Tiruan

Metode Backpropagation (propagasi balik) merupakan metode pembelajaran lanjut yang dikembangkan dari aturan perceptron hal yang ditiru dari perceptrona adalah tahapan dalam algoritma jaringan [6]-[12]. Metode backpropagation ini digunakan untuk menginput data secara manual dan yang akan diteruskan dengan menggunakan metode matlab agar data dan penginputannya cepat dan akurat dengan bantuan matlab [13].

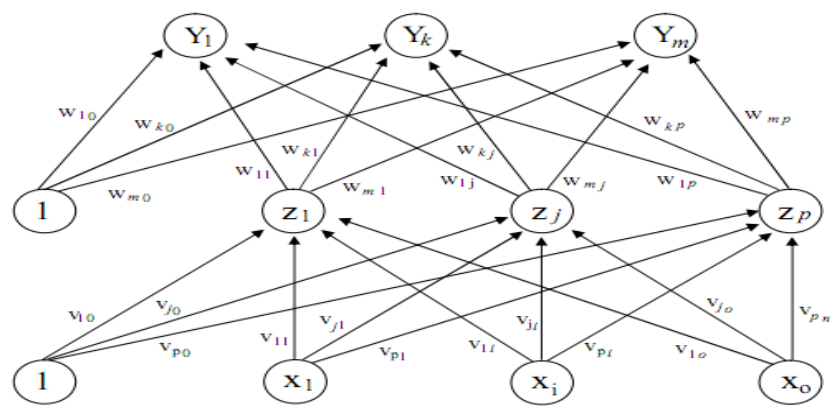

Gambar 2. Model Neuron Sederhana

\subsection{Pelatiahan Jaringan Backpropagation} berikut :

Langkah-langkah dalam algoritma backpropagation oleh adalah sebagai

a. Inisialisasi bobot-bobot dengan bilangan acak kecil, tentukan angka pembelajaran $(\alpha)$. Tentukan pula nilai toleransi error yang diinginkan dan set maksimal epoch jika ingin membatasi jumlah epoch yang digunakan.

b. Jika kondisi penghentian belum terpenuhi, lakukan langkah 2 sampai dengan 9 .

c. Untuk setiap pasangan pola pelatihan, lakukan langkah ke-4 sampai langkah ke-9.

d. Fase Propagasi Maju.

1. Tiap-tiap unit input $\left(\mathrm{X}_{\mathrm{i}}, \mathrm{i}=1,2,3, \ldots, \mathrm{n}\right)$ menerima sinyal input dan meneruskan sinyal tersebut ke tiap-tiap unit pada lapisan tersembunyi.

2. Tiap-tiap unit di lapisan tersembunyi $\left(Z_{j}, j=1,2,3, \ldots, m\right)$ menjumlahkan sinyal-sinyal input yang berbobot, yaitu 


$$
Z_{\text {net } j}=v_{j o}+\sum_{i=0}^{n} x_{i} v_{j i}
$$

Fungsi aktivasi untuk menghitung sinyal outputnya, yaitu:

$Z_{j}=v_{j o}+\sum_{i=0}^{n} x_{i} v_{j i}$

dan mengirimkan sinyal tersebut ke semua unit pada lapisan diatasnya (lapisan output).

3. Tiap-tiap unit di lapisan output $\left(Y_{k}, k=1,2,3, \ldots, p\right)$ menjumlahkan sinyal input yang berbobot, yaitu:

$$
Z_{n e t k}=v_{k o}+\sum_{i=1}^{n} z_{i} w_{k j}
$$

Fungsi aktivasi untuk menghitung sinyal outputnya, yaitu:

$$
Y_{k}=w_{k o}+\sum_{i=1}^{p} Z_{i} W_{k j}
$$

e. Fase Propagasi Mundu

1. Tiap-tiap unit output $Y_{k}$ menerima pola target $t_{k}$ untuk menghitung error $\left(\delta_{\mathrm{k}}\right)$, yaitu:

$d_{k}=\left(t_{k}-Y_{k}\right) f^{\prime}\left(Y_{n e t k}\right)=\left(t_{k}-Y_{k}\right) Y_{k}\left(1-Y_{k}\right)$

Kemudian hitung nilai koreksi bobot yang nantinya digunakan untuk memperbaiki nilai bobot antara lapisan tersembunyi dan lapisan output (wjk), yaitu: $\Delta \mathrm{W}_{\mathrm{kj}}=\alpha \mathrm{d}_{\mathrm{k}} \mathrm{Z}_{\mathrm{j}}$

Hitung juga koreksi bias yang digunakan untuk memperbaiki nilai bias antara lapisan tersembunyi dan lapisan output $\left(\mathrm{w}_{\mathrm{k} 0}\right)$, yaitu:

$\Delta \mathrm{W}_{\mathrm{k} 0}=\alpha \mathrm{d}_{\mathrm{k}}$

2. Tiap-tiap unit pada lapisan tersembunyi $\left(Z_{j}, j=1,2,3, \ldots, m\right)$ menjumlahkan sinyal-sinyal input dari lapisan output, yaitu:

$\Delta \mathrm{W}_{\mathrm{k} 0}=\alpha \mathrm{d}_{\mathrm{k}}$

Kalikan nilai ini dengan fungsi aktivasi untuk menghitung error pada lapisan tersembunyi $\left(\delta_{\mathrm{j}}\right)$, yaitu:

$\mathrm{d}_{\mathrm{j}}=\mathrm{d}_{\text {netj }} \mathrm{f}^{\prime}\left(Z_{n e t_{j}}\right)=\mathrm{d}_{\text {net }} \mathrm{Z}_{\mathrm{j}}\left(1-Z_{\mathrm{j}}\right)$

Kemudian hitung koreksi bobot untuk memperbaiki nilai bobot antara lapisan input dan lapisan tersembunyi $\left(\mathrm{v}_{\mathrm{ji}}\right)$, yaitu:

$\Delta \mathrm{V}_{\mathrm{ji}}=\alpha \mathrm{d}_{\mathrm{j}} \mathrm{X}_{\mathrm{i}}$

Kemudian hitung koreksi bias untuk memperbaiki nilai bobot antara lapisan input dan lapisan tersembunyi $\left(\mathrm{v}_{\mathrm{j} 0}\right)$, yaitu:

$\Delta \mathrm{V}_{\mathrm{j} 0}=\alpha \mathrm{d}_{\mathrm{j}}$

f. Fase Perubahan Bobot

Tiap-tiap unit keluaran $\left(\mathrm{y}_{\mathrm{k}}, \mathrm{k}=1,2,3, \ldots, \mathrm{m}\right)$ memperbaiki bobot dan bias, yaitu: 


$$
\mathrm{W}_{\mathrm{kj}}(\mathrm{baru})=\mathrm{W}_{\mathrm{kj}}(\mathrm{lama})+\Delta \mathrm{W}_{\mathrm{kj}}
$$

\subsection{Peramalan atau Prediksi}

Peramalan atau prediksi merupakan penelaahan tentang situasi yang menyelimuti lingkungan masa datang sebagai dasar pengambilan keputusan. Faktor-faktor yang mempengaruhi-nya sangat banyak seperti halnya oleh berbagai faktor lingkungan yang saling berinteraksi dalam pasar yang berbeda di luar kendali perusahaan, dimana faktor-faktor lingkungan tersebut akan mempengaruhi peramalan [14].

\subsection{Tilang}

Sanksi yang diberikan kepada pelanggar lalu lintas adalah berupa sanksi yang pada umumnya disebut istilah "tilang". Prosedur pelaksanaan tilang ini adalah apabila secara jelas penyidik/penyidik pembantu yang sah secara UndangUndang melihat, mengetahui, terjadinya pelanggaran lalu lintas jalan tertentu sebagaimana tercantum dalam tabel pelanggaran lalu lintas. Pihak peniyidik berhak menindak pelaku pelanggaran lalu lintas dengan ketentuan yang sesuai dengan hukum yang berlaku [15].

\subsection{Metode Pengumpulan Data}

Dalam melakukan penelitian ini, penulis melakukan beberapa metode pengumpulan data, antara lain sebagai berikut :

1. Data Sheet

Data yang digunakan dalam penelitian ini adalah data tilang yang diperoleh dari Kejaksaan Negeri Simalungun mulai tahun 2016 sampai 2018.

2. Pengamatan langsung (Observasi)

Penulis melakukan observasi pada Kejaksaan Negeri Simalungun yang berada pada jalan asahan kabupaten simalungun

3. Studi pustaka

Penulis mencari buku-buku, jurnal atau bahan lain yang penulis jadikan sebagai acuan dari teori-teori yang berhubungan dengan penelitian ini.

Tabel 1 .Tabel Jumlah Tilang

\begin{tabular}{|c|c|c|c|c|c|c|c|c|c|c|c|c|}
\hline & Jan & Feb & Mar & Apr & Mei & Jun & Jul & Agt & Sep & Okt & Nov & Des \\
\hline 2016 & 219 & 255 & 664 & 1250 & 992 & 1128 & 119 & 229 & 504 & 580 & 661 & 996 \\
\hline 2017 & 454 & 1066 & 814 & 639 & 1317 & 1173 & 169 & 507 & 285 & 932 & 2231 & 1162 \\
\hline 2018 & 731 & 149 & 376 & 554 & 2336 & 198 & 195 & 435 & 265 & 335 & 2595 & 1288 \\
\hline
\end{tabular}

Adapun flowchart backpropagation dalam melakukan prediksi dapat dilihat pada gambar 3. 


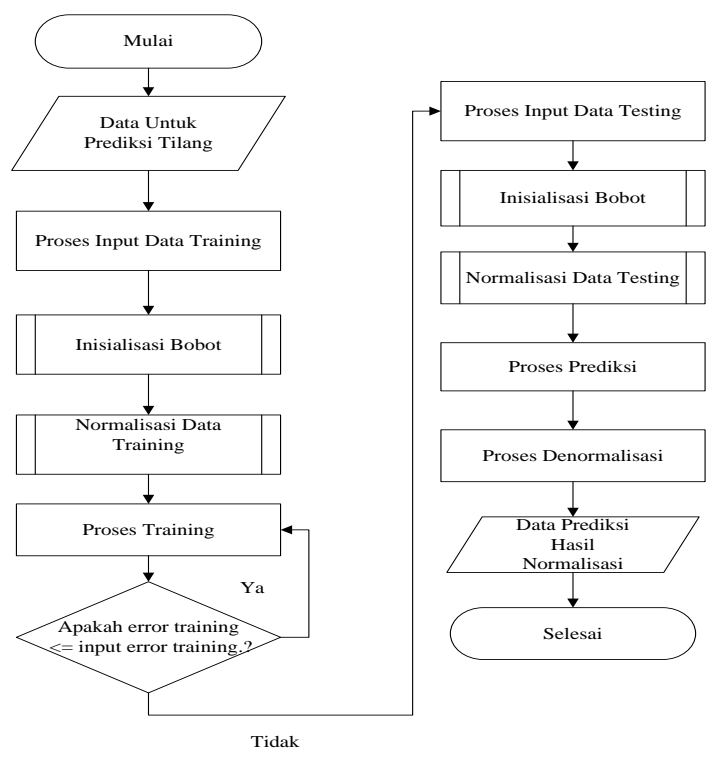

Gambar 3 Flowchart backpropagation

Parameter-parameter dalam pembentukan jaringan backpropagation menggunakan 12 variabel masukan, beberapa lapisan tersembunyi dan 1 lapisan keluaran adalah sebagai berikut :

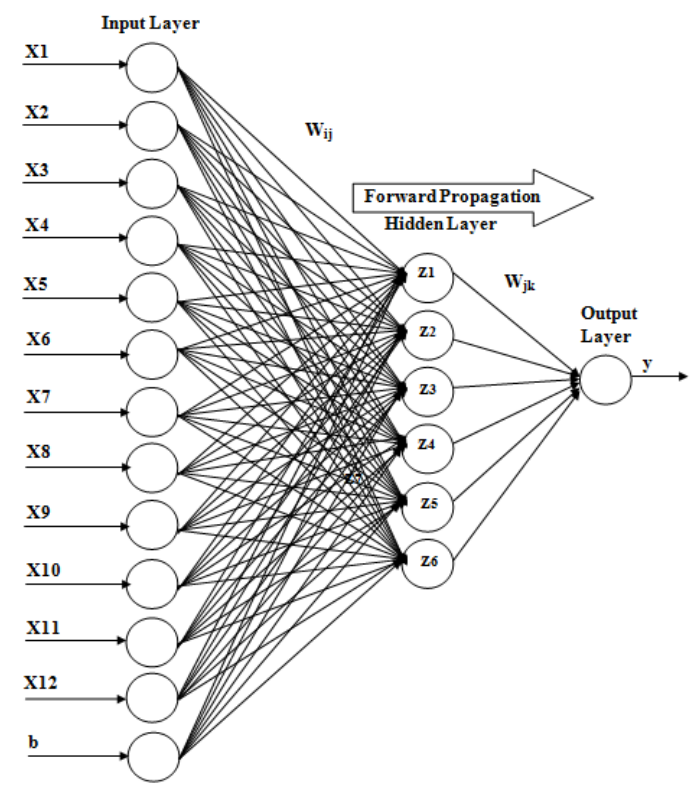

Gambar 4 Arsitektur Backpropagation Prediksi Tilang

Keterangan :
$\mathrm{X}_{1}-\mathrm{X}_{12}$
: Data masukan (input layer)
$\mathrm{b} \quad$ : Bias
$\mathrm{V}_{\mathrm{ij}} \quad$ : Bobot ke simpul hidden
$\mathrm{W}_{\mathrm{ij}} \quad$ : Bobot ke simpul output
$\mathrm{Z}_{1}-\mathrm{Z}_{\mathrm{n}} \quad$ : Hidden layer
Y : Hasil keluaran (output) 
Tabel 2 Tabel Data Training Tahun 2017

\begin{tabular}{|c|c|c|c|c|c|c|c|c|c|c|c|c|c|}
\hline Pola & $\mathbf{X}_{\mathbf{1}}$ & $\mathbf{X}_{\mathbf{2}}$ & $\mathbf{X}_{\mathbf{3}}$ & $\mathbf{X}_{\mathbf{4}}$ & $\mathbf{X}_{\mathbf{5}}$ & $\mathbf{X}_{\mathbf{6}}$ & $\mathbf{X}_{\mathbf{7}}$ & $\mathbf{X}_{\mathbf{8}}$ & $\mathbf{X}_{\mathbf{9}}$ & $\mathbf{X}_{\mathbf{1 0}}$ & $\mathbf{X}_{\mathbf{1 1}}$ & $\mathbf{X}_{\mathbf{1 2}}$ & Target \\
\hline 1 & 219 & 255 & 664 & 1250 & 992 & 1128 & 119 & 229 & 504 & 580 & 661 & 996 & 454 \\
\hline 2 & 255 & 664 & 1250 & 992 & 1128 & 119 & 229 & 504 & 580 & 661 & 996 & 454 & 1066 \\
\hline 3 & 664 & 1250 & 992 & 1128 & 119 & 229 & 504 & 580 & 661 & 996 & 454 & 1066 & 814 \\
\hline 4 & 1250 & 992 & 1128 & 119 & 229 & 504 & 580 & 661 & 996 & 454 & 1066 & 814 & 639 \\
\hline 5 & 992 & 1128 & 119 & 229 & 504 & 580 & 661 & 996 & 454 & 1066 & 814 & 639 & 1317 \\
\hline 6 & 1128 & 119 & 229 & 504 & 580 & 661 & 996 & 454 & 1066 & 814 & 639 & 1317 & 1173 \\
\hline 7 & 119 & 229 & 504 & 580 & 661 & 996 & 454 & 1066 & 814 & 639 & 1317 & 1173 & 169 \\
\hline 8 & 229 & 504 & 580 & 661 & 996 & 454 & 1066 & 814 & 639 & 1317 & 1173 & 169 & 507 \\
\hline 9 & 504 & 580 & 661 & 996 & 454 & 1066 & 814 & 639 & 1317 & 1173 & 169 & 507 & 285 \\
\hline 10 & 580 & 661 & 996 & 454 & 1066 & 814 & 639 & 1317 & 1173 & 169 & 507 & 285 & 932 \\
\hline 11 & 661 & 996 & 454 & 1066 & 814 & 639 & 1317 & 1173 & 169 & 507 & 285 & 932 & 2231 \\
\hline 12 & 996 & 454 & 1066 & 814 & 639 & 1317 & 1173 & 169 & 507 & 285 & 932 & 2231 & 1162 \\
\hline
\end{tabular}

\section{HASIL DAN PEMBAHASAN}

Pengolahan data yang akan dilakukan adalah mengubah data Tilang dengan menggunakan fungsi sigmoid, maka transformasi data dilakukan pada interval yang lebih kecil yaitu $[0,1 ; 0,9][16]-[29]$.

$$
x^{\prime}=\frac{0.8(219-119)}{2231-119}+0.1=0.13787879
$$

Data hasil pengolahan dapat dilihat pada tabel 4.4. berikut :

Tabel 3 Tabel Normalisasi Data

\begin{tabular}{|c|c|c|c|c|c|c|c|}
\hline Pola & $\mathbf{X}_{\mathbf{1}}$ & $\mathbf{X}_{\mathbf{2}}$ & $\mathbf{X}_{\mathbf{3}}$ & $\mathbf{X}_{\mathbf{~}}$ & $\mathbf{X}_{\mathbf{1 1}}$ & $\mathbf{X}_{\mathbf{1 2}}$ & Target \\
\hline 1 & 0.13787879 & 0.1515152 & 0.3064394 & $\ldots$ & 0.305303 & 0.432197 & 0.2268939 \\
\hline 2 & 0.15151515 & 0.3064394 & 0.5284091 & $\ldots$ & 0.432197 & 0.2268939 & 0.4587121 \\
\hline 3 & 0.30643939 & 0.5284091 & 0.4306818 & $\ldots$ & 0.2268939 & 0.4587121 & 0.3632576 \\
\hline 4 & 0.52840909 & 0.4306818 & 0.482197 & $\ldots$ & 0.4587121 & 0.3632576 & 0.2969697 \\
\hline 5 & 0.43068182 & 0.482197 & 0.1 & $\ldots$ & 0.3632576 & 0.2969697 & 0.5537879 \\
\hline 6 & 0.48219697 & 0.1 & 0.1416667 & $\ldots$ & 0.2969697 & 0.5537879 & 0.4992424 \\
\hline 7 & 0.1 & 0.1416667 & 0.2458333 & $\ldots$ & 0.5537879 & 0.4992424 & 0.1189394 \\
\hline 8 & 0.14166667 & 0.2458333 & 0.2746212 & $\ldots$ & 0.4992424 & 0.1189394 & 0.2469697 \\
\hline 9 & 0.24583333 & 0.2746212 & 0.305303 & $\ldots$ & 0.1189394 & 0.2469697 & 0.1628788 \\
\hline 10 & 0.27462121 & 0.305303 & 0.432197 & $\ldots$ & 0.2469697 & 0.1628788 & 0.4079545 \\
\hline 11 & 0.30530303 & 0.432197 & 0.2268939 & $\ldots$ & 0.1628788 & 0.4079545 & 0.9 \\
\hline 12 & 0.43219697 & 0.2268939 & 0.4587121 & $\ldots$ & 0.4079545 & 0.9 & 0.4950758 \\
\hline
\end{tabular}

\subsection{Training Data Dengan Pola 12-6-1}

Data yang akan diolah dengan menggunakan matlab pola arsitektur 12-6

a. Menetapkan Parameter Yang Digunakan

Sebelum dilakukan proses pelatihan data, maka perlu ditetapkan terlebih dahulu parameter-parameter yang diperlukan dalam proses pelatihan. Adapun parameter-parameter yang diperlukan adalah sebagai berikut:

>>net.trainParam.epochs $=10000$;

Parameter ini digunakan untuk menentukan jumlah epoch maksimum pelatihan.

$>>$ net.trainParam.goal $=0.05$;

Parameter ini digunakan untuk menentukan batas nilai MSE agar iterasi dihentikan. Iterasi akan berhenti jika $M S E<$ batas yang ditentukan dalam 
net.trainParam.goal atau jumlah epoch yang telah ditentukan dalam net.trainParam.epochs.

>>net.trainParam.Lr=0.01;

Berdasarkan beberapa percobaan dengan menggunakan parameter learning rate yaitu, 0.01, 0.03, 0.06, 0.09, 0.2, 0.3. dan hasil terbaik diperoleh dari learning rate 0.01 .

$>>$ net.trainParam.show $=1000$;

Parameter ini digunakan untuk menampilkan frekuensi perubahan MSE (default : setiap 25 epoch).

b. Proses Pembentukan Jaringan NET

$>>$ net=train(net,Data_Pelatihan,Target_Pelatihan);

Setelah semua parameter pelatihan dimasukkan, dilakukan running pada software Matlab. Gambar berikut merupakan hasil pelatihan.

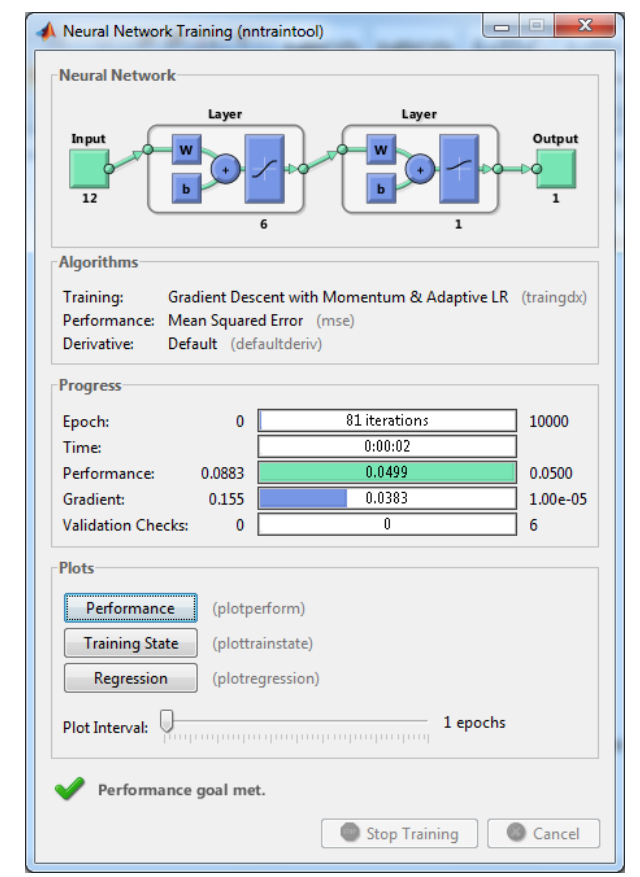

Gambar 5 Hasil Pelatihan pola 12-6-1

Pada gambar 5 diperoleh hasil pelatihan dengan rincian sebagai berikut :

1. Proses pelatihan berhenti pada iterasi 81 dari 10000 iterasi yang diinginkan.

2. Waktu untuk mencapai iterasi 81 adalah 2 detik.

3. Error yang dihasilkan dari parameter tersebut yaitu 0.0439

4. Gradient yang dihasilkan adalah 0.0383

Grafik performance pada pola latihan 12-6-1 dapat dilihat pada gambar 6 berikut ini. 


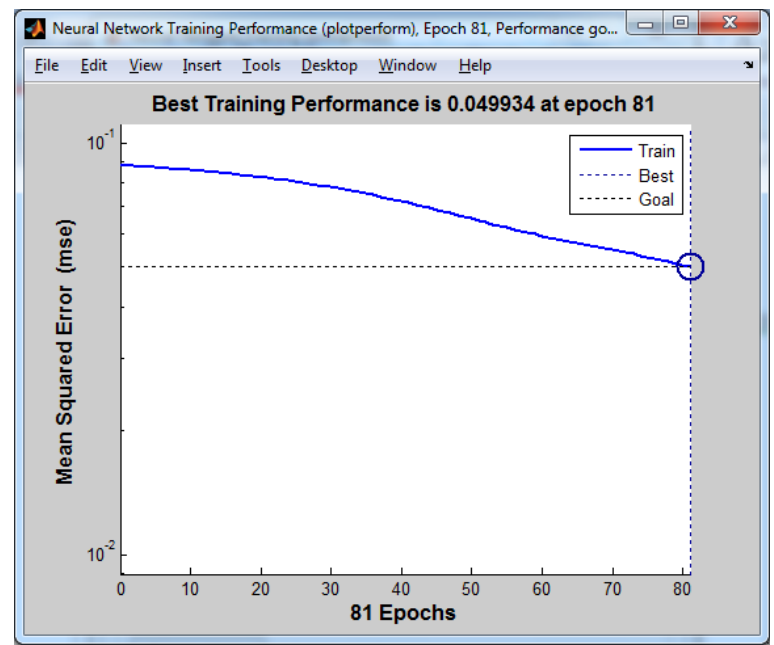

Gambar 6 Grafik performance 12-6-1

Untuk hasil yang lebih rinci dan mengetahui output dan error dapat dilihat pada tabel 4 .

Tabel 4. Hasil dan Error Data Input Pelatihan dengan Model 12 - 6 - 1

\begin{tabular}{|c|c|c|c|c|c|}
\hline Data & Target & Output & ERROR & SSE & Hasil \\
\hline 1 & 0.2268939 & 0.273312 & -0.04642 & 0.002155 & 1 \\
\hline 2 & 0.4587121 & 0.251171 & 0.207541 & 0.043073 & 1 \\
\hline 3 & 0.3632576 & 0.283471 & 0.079787 & 0.006366 & 1 \\
\hline 4 & 0.2969697 & 0.172387 & 0.124583 & 0.015521 & 1 \\
\hline 5 & 0.5537879 & 0.430259 & 0.123528 & 0.015259 & 1 \\
\hline 6 & 0.4992424 & 0.065579 & 0.433663 & 0.188064 & 0 \\
\hline 7 & 0.1189394 & 0.102237 & 0.016702 & 0.000279 & 1 \\
\hline 8 & 0.2469697 & 0.557712 & -0.31074 & 0.096561 & 0 \\
\hline 9 & 0.1628788 & 0.551743 & -0.38886 & 0.151215 & 0 \\
\hline 10 & 0.4079545 & 0.329546 & 0.078409 & 0.006148 & 1 \\
\hline 11 & 0.9 & 0.628194 & 0.271806 & 0.073878 & 0 \\
\hline 12 & 0.4950758 & 0.521421 & -0.02635 & 0.000694 & 1 \\
\hline & & & & 0.599213 & 67 \\
\hline
\end{tabular}

\subsection{Pengujian Data Dengan Pola 12-6-1}

Setelah dilakukan pelatihan dengan pola arsitektur 12-6-1, maka dilanjutkan dengan pengujian data, yang dapat dilihat pada tabel 5. Adapun langkah-langkah pengujian data menggunakan matlab ditetapkan sebagai berikut:

1. Memasukkan data pengujian dengan variabel yang berbeda dengan variabel input pada saat pelatihan.

2. Memasukkan data target pengujian dengan variabel yang berbeda dengan variabel target pada saat pelatihan.

3. Hasil keluaran pengujian data

Untuk melihat hasil yang dikeluarkan oleh jaringan dapat menggunakan perintah sebagai berikut:

$>>$ [HPU,Pf,Af,EPU,Perf]=sim(net,Data_Uji,[],[],Target_Uji);

Berikut ini hasil dari pengujian pola 12-6-1 yang dapat dilihat pada tabel 5 berikut. 
Tabel 5. Hasil dan Error Data Uji dengan Model 12 - 6 - 1

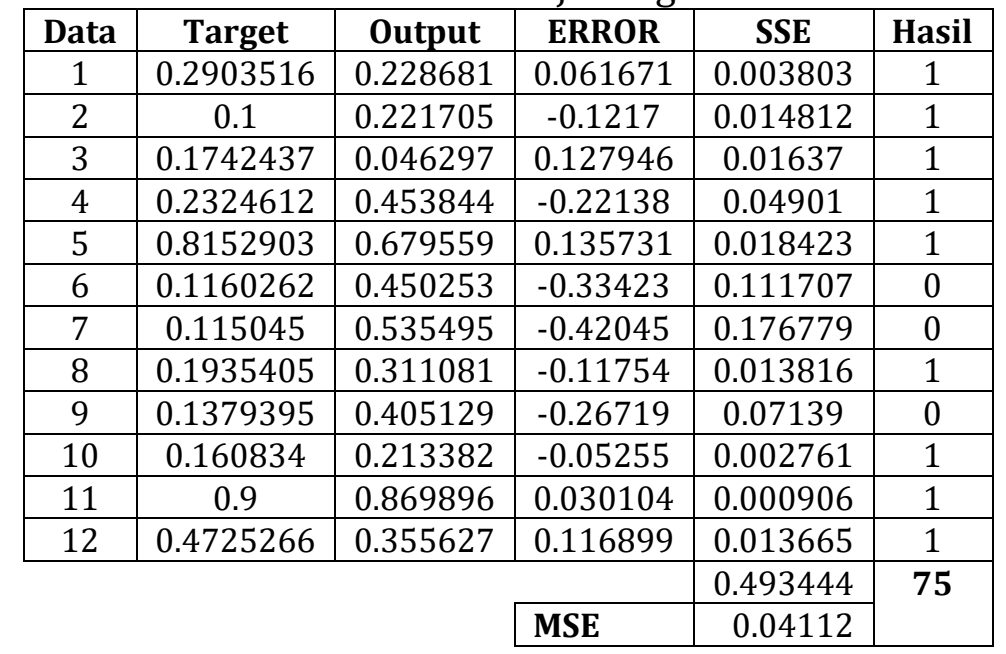

Tabel 6. Perbandingan Model Arsitektur

\begin{tabular}{|c|c|c|c|c|c|c|c|}
\hline \multicolumn{2}{|c|}{} & \multicolumn{6}{|c|}{ Backpropagation } \\
\hline \multirow{2}{*}{ No } & Arsitektur & \multicolumn{5}{|c|}{ Training } & \multicolumn{2}{c|}{ Testing } \\
\cline { 3 - 8 } & & Learning rate & Epoch & Waktu & MSE & MSE & Akurasi \\
\hline 1 & $12-6-1$ & 0.05 & 81 & $00: 02$ & 0.049934 & 0.04112 & $75 \%$ \\
\hline 2 & $12-3-1$ & 0.05 & 107 & $00: 02$ & 0.047872 & 0.151997 & $42 \%$ \\
\hline 3 & $12-4-1$ & 0.05 & 8531 & $02: 29$ & 0.049626 & 0.074512 & $50 \%$ \\
\hline
\end{tabular}

\subsection{Prediksi Tilang}

Tahap terakhir adalah proses prediksi Jumalah Tilang di Kejaksaan Negeri Simalungun. Tahap ini dilakukan dengan menggunakan model arsitektur terbaik yaitu 12-6-1. Data yang akan diprediksi adalah Jumlah tilang tahun 2019 sampai 2020.

1. Prediksi 2019

Ketika melakukan prediksi tahun 2019 data yang akan digunakan adalah data tahun 2016 dan 2017 dengan data yang akan diprediksi tahun 2019. Model yang akan dipakai adalah model arsitektur terbaik yaitu 12-6-1 dengan nilai parameter yang telah ditetapkan sebelumnya. Tabel prediksi tahun 2018 dapat dilihat pada tabel 7.

2. Prediksi 2020

Ketika melakukan prediksi tahun 2020 data yang akan digunakan adalah data tahun 2018 dan 2019 dengan data yang akan diprediksi tahun 2020. Model yang akan dipakai adalah model arsitektur terbaik yaitu 12-6-1 dengan nilai parameter yang telah ditetapkan sebelumnya. Tabel prediksi tahun 2020 dapat dilihat pada tabel 7 .

Tabel 7. Perediksi Tahun 2019

\begin{tabular}{|c|c|c|c|c|c|c|}
\hline \multirow{2}{*}{ No } & \multirow{2}{*}{ Data } & \multicolumn{3}{|c|}{ Input Data } & Prediksi & Prediksi \\
\cline { 3 - 6 } & & $\mathbf{2 0 1 6}$ & $\mathbf{2 0 1 7}$ & $\mathbf{2 0 1 8}$ & $\mathbf{2 0 1 9}$ & $\mathbf{2 0 2 0}$ \\
\hline 1 & Data 1 & 0.13787879 & 0.1997547 & 0.2903516 & 0.09003 & 0.22868108 \\
\hline 2 & Data 2 & 0.15151515 & 0.39991823 & 0.1 & 0.377021 & 0.221704627 \\
\hline 3 & Data 3 & 0.30643939 & 0.31749796 & 0.1742437 & 0.331915 & 0.046297433 \\
\hline 4 & Data 4 & 0.52840909 & 0.26026165 & 0.2324612 & 0.247401 & 0.453843651 \\
\hline 5 & Data 5 & 0.43068182 & 0.48201145 & 0.8152903 & 0.441163 & 0.679559049 \\
\hline
\end{tabular}




\begin{tabular}{|c|c|c|c|c|c|c|}
\hline No & Data & \multicolumn{3}{|c|}{ Input Data } & Prediksi & Prediksi \\
\cline { 3 - 7 } & & $\mathbf{2 0 1 6}$ & $\mathbf{2 0 1 7}$ & $\mathbf{2 0 1 8}$ & $\mathbf{2 0 1 9}$ & $\mathbf{2 0 2 0}$ \\
\hline 6 & Data 6 & 0.48219697 & 0.43491415 & 0.1160262 & 0.322504 & 0.45025274 \\
\hline 7 & Data 7 & 0.1 & 0.10654129 & 0.115045 & 0.251886 & 0.535495449 \\
\hline 8 & Data 8 & 0.14166667 & 0.21708913 & 0.1935405 & 0.483702 & 0.311080968 \\
\hline 9 & Data 9 & 0.24583333 & 0.14448078 & 0.1379395 & 0.573669 & 0.405128898 \\
\hline 10 & Data 10 & 0.27462121 & 0.35609158 & 0.160834 & 0.617014 & 0.213381803 \\
\hline 11 & Data 11 & 0.30530303 & 0.78094849 & 0.9 & 0.97088 & 0.869896094 \\
\hline 12 & Data 12 & 0.43219697 & 0.43131643 & 0.4725266 & 0.22018 & 0.355627133 \\
\hline
\end{tabular}

Tahap selanjutnya melakukan proses denormalisasi, yaitu mengubah bilangan angka yang telah diprediksi kedalam bilangan data tahap awal. Proses denormalisasi dilakukan dengan menggunakan rumus $. X^{\prime}=\frac{(x-0.1) *(b-a)}{0.8+a}$. Data denormalisasi pada penelitian ini dapat dilihat pada tabel 8. berikut :

Tabel 8. Tabel Denormalisasi

\begin{tabular}{|c|c|c|c|}
\hline \multirow{2}{*}{ No } & \multirow{2}{*}{ Data } & \multicolumn{2}{|c|}{ Input Data } \\
\cline { 3 - 4 } & & $\mathbf{2 0 1 9}$ & $\mathbf{2 0 2 0}$ \\
\hline 1 & Data 1 & 117 & 566 \\
\hline 2 & Data 2 & 1048 & 544 \\
\hline 3 & Data 3 & 901 & 25 \\
\hline 4 & Data 4 & 627 & 1297 \\
\hline 5 & Data 5 & 1256 & 2029 \\
\hline 6 & Data 6 & 871 & 1285 \\
\hline 7 & Data 7 & 642 & 1562 \\
\hline 8 & Data 8 & 1394 & 834 \\
\hline 9 & Data 9 & 1685 & 1139 \\
\hline \multirow{2}{*}{ No } & \multirow{2}{*}{ Data } & \multicolumn{2}{|c|}{ Input Data } \\
\cline { 3 - 4 } & & 2019 & 2020 \\
\hline 10 & Data 10 & 1826 & 517 \\
\hline 11 & Data 11 & 2974 & 2646 \\
\hline 12 & Data 12 & 539 & 978 \\
\hline
\end{tabular}

\section{KESIMPULAN}

Kesimpulan yang dapat diambil setelah melakukan pelatihan dan pengujian data pada jaringan syaraf tiruan dengan menggunakan algoritma backpropagation adalah sebagai berikut :

1. Arsitektur Backpropogation dibentuk dengan beberapa model, Pemodelan backpropagation dibagi menjadi 2 yaitu model pelatihan dan model pengujian. Model pelatihan dilakukan dengan menggunakan jumlah variabel input yaitu tahun 2016 dengan target tahun 2017, hidden layer dan output. Model pengujian dilakukan dengan menggunakan jumlah variabel input yaitu tahun 2017 dengan target tahun 2018, hidden layer dan output. Dari model tersebut dijadikan sebuah arsitektur 12-6-1 dan seterusnya. Pada penelitian ini arsitektur yang digunakan adalah 12-6-1, 12-3-1, dan 12-4-1, dengan menggunakan masing-masing learning rate yang sama.

2. Arsitektur terbaik pada penelitian ini adalah 12-6-1 dengan menggunakan learning rate 0.05 , MSE 0.03458058 , nilai toleransi minimum pada penelitian ini adalah 0.001 dan mendapatkan tingkat akurasi sebesar 75\%. Dengan pola 12-6-1 tersebut selanjutnya dilakukan prediksi untuk tahun 2019 sampai 
dengan 2020 dengan demikian metode Backpropogation sesuai dan relevan dalam memprediksi jumlah tilang di Kejaksaan Negeri Simalungun.

\section{DAFTAR PUSTAKA}

[1] A. Wanto and A. P. Windarto, "Analisis Prediksi Indeks Harga Konsumen Berdasarkan Kelompok Kesehatan Dengan Menggunakan Metode Backpropagation," Jurnal \& Penelitian Teknik Informatika Sinkron, vol. 2, no. 2, pp. 37-44, 2017.

[2] A. Wanto, A. P. Windarto, D. Hartama, and I. Parlina, "Use of Binary Sigmoid Function And Linear Identity In Artificial Neural Networks For Forecasting Population Density," International Journal Of Information System \& Technology, vol. 1, no. 1, pp. 43-54, 2017.

[3] A. Wanto, M. Zarlis, Sawaluddin, and D. Hartama, "Analysis of Artificial Neural Network Backpropagation Using Conjugate Gradient Fletcher Reeves in the Predicting Process," Journal of Physics: Conference Series, vol. 930, no. 1, pp. 1-7, 2017.

[4] E. P. Cynthia et al., "JARINGAN SYARAF TIRUAN ALGORITMA BACKPROPOGATION DALAM MEMPREDIKSI KETERSEDIAAN KOMODITI PANGAN PROVINSI RIAU," RABIT Jurnal Teknologi dan Sistem Informasi Univrab), vol. 2, no. 2, pp. 196-209, 2017.

[5] Y. A. Lesnussa, S. Latuconsina, and E. R. Persulessy, "Aplikasi Jaringan Saraf Tiruan Backpropagation untuk Memprediksi Prestasi Siswa SMA ( Studi kasus : Prediksi Prestasi Siswa SMAN 4 Ambon )," Jurnal Matematika Integratif, vol. 11, no. 2, pp. 149-160, 2015.

[6] S. P. Siregar and A. Wanto, "Analysis of Artificial Neural Network Accuracy Using Backpropagation Algorithm In Predicting Process (Forecasting)," International Journal of Information System \& Technology, vol. 1, no. 1, pp. 34-42, 2017.

[7] J. R. Saragih, M. Billy, S. Saragih, and A. Wanto, "Analisis Algoritma Backpropagation Dalam Prediksi Nilai Ekspor (Juta USD)," Jurnal Pendidikan Teknologi dan Kejuruan, vol. 15, no. 2, pp. 254-264, 2018.

[8] E. Hartato, D. Sitorus, and A. Wanto, "Analisis Jaringan Saraf Tiruan Untuk Prediksi Luas Panen Biofarmaka di Indonesia," Jurnal semanTIK, vol. 4, no. 1, pp. 49-56, 2018.

[9] S. Setti and A. Wanto, "Analysis of Backpropagation Algorithm in Predicting the Most Number of Internet Users in the World," JOIN (Jurnal Online Informatika), vol. 3, no. 2, pp. 110-115, 2018.

[10] R. E. Pranata, S. P. Sinaga, and A. Wanto, "Estimasi Wisatawan Mancanegara Yang Datang ke Sumatera Utara Menggunakan Jaringan Saraf," Jurnal semanTIK, vol. 4, no. 1, pp. 97-102, 2018.

[11] A. A. Fardhani, D. Insani, N. Simanjuntak, and A. Wanto, "Prediksi Harga Eceran Beras Di Pasar Tradisional Di 33 Kota Di Indonesia Menggunakan Algoritma Backpropagation," Jurnal Infomedia, vol. 3, no. 1, pp. 25-30, 2018.

[12] J. Wahyuni, Y. W. Paranthy, and A. Wanto, "Analisis Jaringan Saraf Dalam Estimasi Tingkat Pengangguran Terbuka Penduduk Sumatera Utara," Jurnal Infomedia, vol. 3, no. 1, pp. 18-24, 2018.

[13] Y. Novryanti and B. Mangunsong, "IMPLEMENTASI JARINGAN SYARAF TIIRUAN UNTUK MEMPREDIKSI JUMLAH PENJUALAN SARIAYU DENGAN MENGGUNAKAN METODE BACKPROPOGATION (STUDI KASUS : PT. SAI INDONESIA)," pp. 120-128, 2017.

[14] Y. A. Nada, "Prediksi Kesehatan Koperasi Dengan Jaringan Syaraf Tiruan Metode Backpropagation," 2017.

[15] Wagiyah, Holilluloh, and M. M. Adha, "PENGARUH SANKSI TILANG BAGI PELANGGAR TERHADAP KEDISIPLINAN DALAM BERLALU LINTAS," Animal Genetics, vol. 39, no. 5, pp. 561-563, 2008.

[16] A. Wanto et al., "Levenberg-Marquardt Algorithm Combined with Bipolar Sigmoid Function to Measure Open Unemployment Rate in Indonesia," in Conference Paper, 2018, pp. 1-7.

[17] I. A. R. Simbolon, F. Yatussa'ada, and A. Wanto, "Penerapan Algoritma Backpropagation dalam Memprediksi Persentase Penduduk Buta Huruf di Indonesia," Jurnal Informatika Upgris, vol. 4, no. 2, pp. 163-169, 2018.

[18] S. P. Siregar, A. Wanto, and Z. M. Nasution, "Analisis Akurasi Arsitektur JST Berdasarkan Jumlah Penduduk Pada Kabupaten / Kota di Sumatera Utara," in Seminar Nasional Sains \& Teknologi Informasi (SENSASI), 2018, pp. 526-536.

[19] A. Wanto, "Optimasi Prediksi Dengan Algoritma Backpropagation Dan Conjugate Gradient 
Beale-Powell Restarts," Jurnal Teknologi dan Sistem Informasi, vol. 3, no. 3, pp. 370-380, Jan. 2018.

[20] B. K. Sihotang and A. Wanto, “Analisis Jaringan Syaraf Tiruan Dalam Memprediksi Jumlah Tamu Pada Hotel Non Bintang," Jurnal Teknologi Informasi Techno, vol. 17, no. 4, pp. 333346, 2018.

[21] M. A. P. Hutabarat, M. Julham, and A. Wanto, "Penerapan Algoritma Backpropagation Dalam Memprediksi Produksi Tanaman Padi Sawah Menurut Kabupaten/Kota di Sumatera Utara," Jurnal semanTIK, vol. 4, no. 1, pp. 77-86, 2018.

[22] Y. Andriani, H. Silitonga, and A. Wanto, "Analisis Jaringan Syaraf Tiruan untuk prediksi volume ekspor dan impor migas di Indonesia," Register - Jurnal Ilmiah Teknologi Sistem Informasi, vol. 4, no. 1, pp. 30-40, 2018.

[23] A. Wanto, "Penerapan Jaringan Saraf Tiruan Dalam Memprediksi Jumlah Kemiskinan Pada Kabupaten/Kota Di Provinsi Riau," Kumpulan jurnaL Ilmu Komputer (KLIK), vol. 5, no. 1, pp. 61-74, 2018.

[24] I. S. Purba and A. Wanto, "Prediksi Jumlah Nilai Impor Sumatera Utara Menurut Negara Asal Menggunakan Algoritma Backpropagation,” Jurnal Teknologi Informasi Techno, vol. 17, no. 3, pp. 302-311, 2018.

[25] A. Wanto, "Prediksi Angka Partisipasi Sekolah dengan Fungsi Pelatihan Gradient Descent With Momentum \& Adaptive LR," Jurnal Ilmu Komputer dan Informatika (ALGORITMA), vol. 3, no. 1, pp. 9-20, 2019.

[26] N. Nasution, A. Zamsuri, L. Lisnawita, and A. Wanto, "Polak-Ribiere updates analysis with binary and linear function in determining coffee exports in Indonesia," IOP Conference Series: Materials Science and Engineering, vol. 420, no. 12089, pp. 1-9, 2018.

[27] A. Wanto, "Prediksi Produktivitas Jagung Indonesia Tahun 2019-2020 Sebagai Upaya Antisipasi Impor Menggunakan Jaringan Saraf Tiruan Backpropagation," SINTECH (Science and Information Technology), vol. 1, no. 1, pp. 53-62, 2019.

[28] B. Febriadi, Z. Zamzami, Y. Yunefri, and A. Wanto, "Bipolar function in backpropagation algorithm in predicting Indonesia's coal exports by major destination countries," IOP Conference Series: Materials Science and Engineering, vol. 420, no. 12089, pp. 1-9, 2018.

[29] A. Wanto et al., "Analysis of Standard Gradient Descent with GD Momentum And Adaptive LR for SPR Prediction," 2018, pp. 1-9. 